\title{
OBTAINING FUNDS ON THE BASIS OF LEASING IN THE REPUBLIC OF SRPSKA
}

\author{
Slavko Lošić ${ }^{1}$, Mirko Malinović ${ }^{2}$, Milica Jovanović ${ }^{3}$ \\ 12 Business Economics Academy Čačak \\ ${ }^{3}$ NovateQ Global
}

Corresponding: slavko.losic@gmail.com

Review article

Received: 15.10.2020; Accepted: 27.11.2020

\begin{abstract}
This paper is dedicated to leasing operations in the Republic of Srpska, which are regulated by law. ${ }^{1}$ Leasing is a legal transaction where the lessor transfers the right to hold and use the leased object to the lessee for a certain period, with his obligation to pay the agreed leasing fee and with the right to return the leased object to the lessor, buy it or extend the lease agreement.

This way of financing is mostly used by newly established, small and medium enterprises, which do not already have the amount of funds needed to obtain investment goods. By concluding a leasing contract, the lessee does not acquire the right of ownership over the object of leasing, but acquires economic benefits from the use of the object of leasing. The lease agreement usually coincides in time with the useful life of the assets, i.e. the period of depreciation calculation. The practice is that the same contract allows the lessee to repurchase the leased asset at a symbolic price.
\end{abstract}

Keywords: leasing, financial leasing, leasing contract, lessor, lessee, subject of leasing, economic benefits from the subject of leasing.

\section{Introduction}

We live in time and we are witnessing the process of globalization of the world, whose policy is based on the global market economy, the power of developed capitalist countries and their transnational companies that are developing with the wholehearted help of international financial institutions. At the same time, newly established, small and medium-sized legal entities do not have enough of their own funds to acquire specific investment goods (real estate, equipment and consumer goods). The specificity of 
these goods in relation to other assets is reflected, among other things, that they are assets of great value and with a longer lifespan (longer than one year), and these legal entities do not have enough of their own sources of funding to obtain them. These are the reasons that influenced and led to the creation of new methods of financing the purchase of investment goods.

In international business practice, the Leasing Agreement is one of those well-represented methods of financing in which producers of investment goods have found their interest in increasing the volume of sales of their products and conquering new markets. financing. Under the lease agreement, the lessee undertakes to pay the lessor a fee for holding and using the leased object at the agreed time, and ownership of the leased object is not the primary category, because the right of economic use is given priority. Formally and legally, by concluding a leasing contract, the lessee does not acquire the right of ownership over the object of leasing, but essentially acquires economic benefits from the use of the object of leasing during most of its economic life. The agreed duration is usually slightly shorter than the economic life of the leased asset and coincides with the depreciation period, ie the useful life of the asset. It is custom- ary to give the lessee the opportunity to purchase the leased asset at the expiration of the lease agreement, at a symbolic price.

Leasing operations in the Republic of Srpska are performed in accordance with the provisions of the Leasing Law, which, among other things, defines the terms leasing and financial leasing. ${ }^{2}$

In that sense, leasing is defined as a legal transaction in which the lessor transfers the right to hold and use the leased object to the lessee for a certain period, with his obligation to pay the agreed leasing fee and the right to return the leased object to the lessor, buy it or extend lease agreement. Financial leasing is defined as a legal transaction in which the lessor:

a) concludes a delivery contract with the supplier of the leased object designated by the lessee on the basis of which he acquires the right of ownership over the leased object, according to the lessee's specification and under conditions approved by the lessee, if they relate to the lessee's interests;

b) concludes a financial leasing contract with the lessee, which obliges him to transfer to the lessee the authority to hold and use the leased object for the agreed time, and the lessee undertakes to pay him the agreed lease fee, 
c) the leasing fee is determined on the basis of depreciation of the whole or the most important part of the value of the leased object.

A contract in which the lessor and the supplier of the leased object are the same person is not considered a financial leasing contract, but an operating leasing contract. In the case of an operating lease, the leased asset is assigned for a shorter or indefinite period of time with a shorter notice period, the lessee bears the maintenance costs, and the lessor bears the risk of accidental destruction.

In addition to the above, the legislator has determined the concept of financial leasing contract as well as the content, i.e. mandatory elements of the contract; conditions that entities must meet to perform leasing operations; minimum amount of share capital of the lessor; rights, obligations and responsibilities of the leasing entity; termination of the leasing contract, registration of property rights over the subject of leasing and other provisions.

The rules and requirements for accounting and recording business transactions arising from leasing agreements are contained in International Financial Reporting Standards, primarily in IAS 17 Leasing $^{3}$ and other relevant standards that require or permit dif- ferent accounting treatment, which is based on a different approach from the approach prescribed in this standard.

\section{Regulatory framework}

There are several different sources on the timing of the Leasing Agreement. The recorded traces of the initial leasing business date back to the distant past. The oldest civilizations of Egypt, Greece and the Roman Empire used property rental transactions for personal and social needs. In Mesopotamia, the city of the Sumerians in Ur, the first leasing transaction from 2010 was found on clay records. BC, and the first records of the leasing law were found in the famous Code of Hammurabi of the Babylonian emperor, which dates back to around 1700. BC (according to medieval chronology). In the United States, which is considered the country of origin of leasing, in the $18^{\text {th }}$ century leasing appeared in the form of financing horse-drawn carriages.

Due to the rapid growth of the transport industry (railways), railway owners use new financing methods to finance the purchase of locomotives, wagons and other railway equipment, which include third parties - investors, who invest their money in the purchase of railway equipment and then rent it to railway companies. equipment trust certificates. Railways become 
the owners of that equipment only when they repay the purchase value of the equipment increased by the accrued interest. Since 1877, instead of selling, Bell-TelephonCompany has leased its telephone in the form of leasing as well as real estate financing since the 1930s. In that sense, the United States is considered the country of origin of leasing business, which is also accepted by other industrialized countries in the 1950s.

Leasing operations in the Republic of Srpska are performed in accordance with the provisions of the Leasing Law, adopted for the first time in 2007, which created the legal framework for performing these operations. This law regulates leasing operations, and in cases not regulated by this law, the provisions of the law governing obligations and the provisions of other laws shall apply.

Certain terms used in the Leasing Act have the following meanings 4 :

"Lessor" is a person who has received a license from the Banking Agency of Republic of Srpska to perform leasing activities in accordance with the Leasing Law and who transfers to the lessee the right to hold and use the leased object for the agreed period, for which he receives leasing compensation.
Lessee is a legal or natural person to whom the lessor transfers the right to hold and use the leased object.

"Supplier of the leased object" is a legal or natural person who transfers to the lessor the right of ownership over the leased object, for the purpose of handing it over to the lessee for holding and use, in accordance with the leasing contract.

"Subject of leasing" is a movable and unspent thing or an immovable thing in accordance with the regulations governing real rights.

"Leasing fee" is the amount of money paid in installments by the lessee for holding and using the leased asset.

"Delivery agreement" is a written agreement concluded between the supplier of the leased asset and the lessor on the basis of which the lessor acquires the right of ownership over the leased asset for the purpose of its leasing.

The subjects in the leasing business are: the lessor, the lessee and the supplier of the leased object.

In addition to the cited provisions, the Leasing Law regulates other issues related to the performance of leasing activities. The following table provides an overview of the legal provisions governing these issues: 
Table number 1. Overview of legal provisions

\begin{tabular}{|l|l|l|}
\hline Regulation & Area & Law clause \\
\hline \multirow{2}{*}{$\begin{array}{l}\text { Leasing Low } \\
\text { Gazficial }\end{array}$} & General conditions & Clause. $1-9$ \\
\cline { 2 - 3 } $\begin{array}{l}\text { No. } 70 / 07, \\
116 / 11)\end{array}$ & Doing leasing & Clause. $10-23$ \\
\cline { 2 - 3 } & $\begin{array}{l}\text { Rights and obligations of } \\
\text { the leasing entity }\end{array}$ & Clause. 24 - 49 \\
\cline { 2 - 3 } & $\begin{array}{l}\text { Termination of the lease } \\
\text { agreement }\end{array}$ & Clause. 50 - 51 \\
\cline { 2 - 3 } & $\begin{array}{l}\text { Registration of property } \\
\text { rights over the subject of } \\
\text { leasing }\end{array}$ & Clause. 52-57 \\
\cline { 2 - 3 } & Reporting and auditing & Clause. 58 - 59 \\
\cline { 2 - 3 } & $\begin{array}{l}\text { Business supervision and } \\
\text { license revocation }\end{array}$ & Clause. 60 - 68 \\
\cline { 2 - 3 } & Penal provisions & Clause. 69-73 \\
\hline
\end{tabular}

Entities in the leasing business in the Republic of Srpska have the obligation to comply with the prescribed provisions of the Leasing Law as well as the requirements and rules contained in the international standards applicable in the Republic of Srpska.

Bosnia and Herzegovina (and thus the Republic of Srpska), since 2000, approaching European integration, has committed itself to, accepted and applied International Standards (including International Accounting Standards). In the Republic of Srpska, the first reforming Law on Accounting and Auditing from 1999 prescribes the mandatory application of International Accounting Standards. The following - later adopted Accounting and Auditing Law (from 2005,
2009 and 2015) prescribe the mandatory application of International Accounting Standards, as well as the application of accompanying regulations adopted by relevant international accounting bodies and support their full (immediate) application.

InIAS 17 - Leasing contains requirements and rules for accounting for business transactions arising under a finance lease. The requirements and rules indicate that the coverage and presentation of these transactions is performed in accordance with the substance and financial reality, and not only with the legal form. Formally and legally, by concluding a leasing contract, the lessee does not acquire the right of ownership over the object of leasing, but essentially 
acquires economic benefits from the use of the object of leasing during most of its economic life. Assets and liabilities based on the subject of leasing are recognized in the balance sheet. If the assets and liabilities on the basis of leasing would not be recognized in the balance sheet, the total assets and liabilities of the lessee would not give a true picture of the financial position, ie assets and liabilities would be underestimated. Therefore, an asset that is the subject of a finance lease is recognized in the balance sheet of the lessee as an asset and as a liability to pay in respect of the lease.

\section{Initial recognition and valuation}

The lessee in connection with a finance lease in the balance sheet initially recognizes an asset and a liability in an amount that is one sum lower than the following two values:

- the fair value of the leased asset or the present value of the minimum lease payments and

- all initial (initial) direct leasing costs.

Initial leasing costs include expenses incurred in connection with the negotiation and securing of a leasing agreement when they can be directly attributed to the activities that the lessee has in connection with financial leasing. Therefore, these expenses are included in the initial value of assets in the form of leasing.

When calculating the present value of the minimum lease payments, the discount rate is, if it can be determined, the interest rate conained in the lease. If it cannot be determined, the tenant's increental interest rate is used.

Annuity, ie payment for leasing, consists of two parts:

- leasing obligations and

- interest

Financial expenses should be allocated to periods during the lease term, so that in all these periods the same interest rate is obtained, observed in relation to the remaining amount of leasing liabilities. Over time, the expenses will be lower and lower, because the repayment reduces the obligtion, and therefore the basis for calculating financial expenses.

Contingencies costs related to lease payments are recognized as an expense in the period in which they are incurred. Financial leasing of the lessee causes two types of expenses:

- depreciation expenses for leased assets and

- interest expenses included in the leasing value 
Depreciation calculation for leased assets is performed as well as depreciation calculation for the same assets owned by a legal entity in terms of the rules contained in IAS 16 - Property, Plant and Equipment. Determining the useful life of an asset depends on the certainty of whether the lessee will become the owner of the asset upon the expiration of the lease. If it is certain, the useful life of the asset is the period in which depreciation is calculated, ie. the period in which the asset should be depreciated. For example, if that period (useful life) is 5 years, the depreciation rate is $20 \%$, assuming the linear depreciation method is used. If this certainty does not exist, the useful life will be equal to the lease term and depreciation will be calculated over the lease term. For example, the lease term is 4 years, and the possible useful life of the asset is 5 years, the depreciation rate is calculated based on the lease term, because the lessee will return the asset after the fourth year. In this example, the annual depreciation rate would be $25 \%$, assuming the linear depreciation method is used.

The lessee checks whether the leased assets are impaired. It does that in the same way as for owned assets, at least on each balance sheet date by applying the rules contained in IAS 16 Property, Plant and Equipment and IAS 36 Impairment of Assets.

\section{Example:}

The legal entity "X" doo Pale, from the lessor "Y" took the equipment with a sales value of $50,000.00 \mathrm{KM}$. The purchase value of the equipment from the lessor is $40,000.00 \mathrm{KM}$.

The interest rate contained in the lease is $10 \%$.

The VAT rate is $17 \%$.

The useful life of the equipment is 5 years.

Repayment is annual and is paid at the end of the year.

By repaying the last installment, the lessee becomes the owner of the equipment. 


\subsection{Calculations before posting}

From the above example, it can be concluded that the conditions for classifying the leasing arrangement into financial leasing have been met.

Before posting, it is necessary to calculate the amount of the annuity and compile a repayment plan. In practice, it is common for the lessor to calculate the annuity amounts and compile a repayment list which it submits to the lessee.

Annuities are calculated according to the following form 5 :

$$
\begin{aligned}
& a=g \times \frac{r^{n}(r-1)}{r^{n}-1} \\
& r=1+\frac{p}{100}
\end{aligned}
$$

wherein:

a - annuity

g- principal

p - interest rate contained in the lease

$\mathrm{n}$ - number of periods

$$
r=1+\frac{10}{100}=1,10
$$

$$
n=5
$$$$
a=50.000,00 \times \frac{1,10^{5}(1,10-1)}{1,10^{5}-1}=13.189,50 K M
$$

$n=5$

\section{Annuity $=13,189.50 \mathrm{KM}$}

The total amount paid by the lessee is $65,947.50 \mathrm{KM}(13,189.50 \mathrm{KM}$ $\mathrm{x} 5$ years). This means that the interest is $15,947.50 \mathrm{KM}$ for the entire leasing period. 
Table no. 2. Annuity repayment plan

\begin{tabular}{|c|c|c|c|c|}
\hline Year & $\begin{array}{c}\text { Annual } \\
\text { Annuity }\end{array}$ & $\begin{array}{c}\text { Annual } \\
\text { interest }\end{array}$ & $\begin{array}{c}\text { Annual } \\
\text { principal }\end{array}$ & $\begin{array}{c}\text { Rest of a } \\
\text { debt }\end{array}$ \\
\hline 1 & 2 & 3 & 4 & 5 \\
\hline & & & & $50.000,00$ \\
1. & $13.189,50$ & $5.000,00$ & $8.189,50$ & $41.810,50$ \\
2. & $13.189,50$ & $4.181,05$ & $9.008,45$ & $32.802,05$ \\
3. & $13.189,50$ & $3.280,20$ & $9.909,30$ & $22.892,75$ \\
4. & $13.189,50$ & $2.289,25$ & $10.900,25$ & $11.992,50$ \\
5. & $13.189,50$ & $1.197,00$ & $11.992,50$ & 0,00 \\
\hline Total: & $65.947,50$ & $15.947,50$ & $50.000,00$ & \\
\hline
\end{tabular}

Method of calculating individual amounts in the table:

Column 2: The manner in which the amount for the annual annuity was determined can be seen from the previously presented forms for calculating the annuity;

Column 3: The annual amount of interest for the first year of $5,000.00 \mathrm{KM}$ is obtained when multiplying the remaining debt (from the previous row) 50,000.00 KM with an interest rate of $10 \%$. The amount of 4,181.05 KM for the second year is obtained when the remaining debt of $41,810.50 \mathrm{KM}$ is multiplied by the interest rate of $10 \%$, etc.;

Column 4: The amount of annual principal for the first year of $8,189.50 \mathrm{KM}$ is obtained when the amount of interest in that year $(5,000.00 \mathrm{KM})$ is deducted from the amount of annuity $(13,189.50 \mathrm{KM})$, etc.;
Column 5: The fair value of the leased asset leased is KM $50,000.00$. The amount of the remaining principal after the payment of the first annuity $(41,810.50 \mathrm{KM})$ is obtained when the amount of the paid first annual principal $(50,000.00-8,189.50=$ $41,810.00$ ) is deducted from the amount of 50,000.00 KM, etc.

\subsection{VAT calculation}

The value added tax rate applied in the Republic of Srpska is a single rate of $17 \%$.

In practice, the basis for calculating value added tax at the lessee is determined:

a) in such a way that value added tax is calculated at the time of financial leasing, on the basis of the sum of the amount of principal and total interest.

In the given example, the calculation would be: 
Lošić S. et al., Obtaining funds on the basis of leasing in the Republic of Srpska

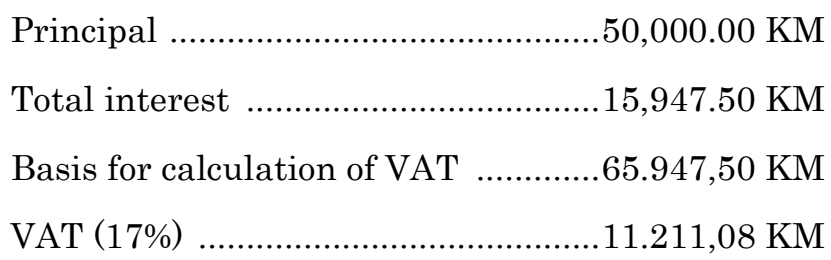

b) in such a way that the calculation of value added tax is calculated at the moment of maturity of the annuity for collection, on the amount of the base which is equal to the amount of the due annuity for collection.

In the given example, the calculation would be:

Due annuity for payment $13,189.50 \mathrm{KM}$

Basis for VAT calculation $13.189,50 \mathrm{KM}$

VAT (17\%) $2.242,22 \mathrm{KM}$

The calculation is performed by the lessor in accordance with legal regulations and than it is been delivered to the lessee.

\subsection{Depreciation calculation}

For the stated asset taken into financial leasing, the depreciation calculation is performed as well as the depreciation calculation for the same assets that are owned by the legal entity, in terms of the rules contained in IAS 16 - Property, Plant and Equipment. In this $\mathrm{ex}^{-}$ ample, the useful life would be equal to the lease term, and the depreciation would be calculated within the lease term.

By applying the linear method of depreciation calculation, the depreciation calculation would be:

$$
\text { AnnualDepreciationRate }=\frac{100}{5 \text { years }}=20 \%
$$

Annual amount depreciation=50,000.00 x 20\% = 10,000.00 KM 


\subsection{Posting in the Financial Accounting General Ledger ${ }^{6}$}

Posting in the first year would be : $^{7}$

Diary of the general ledger of financial accounting

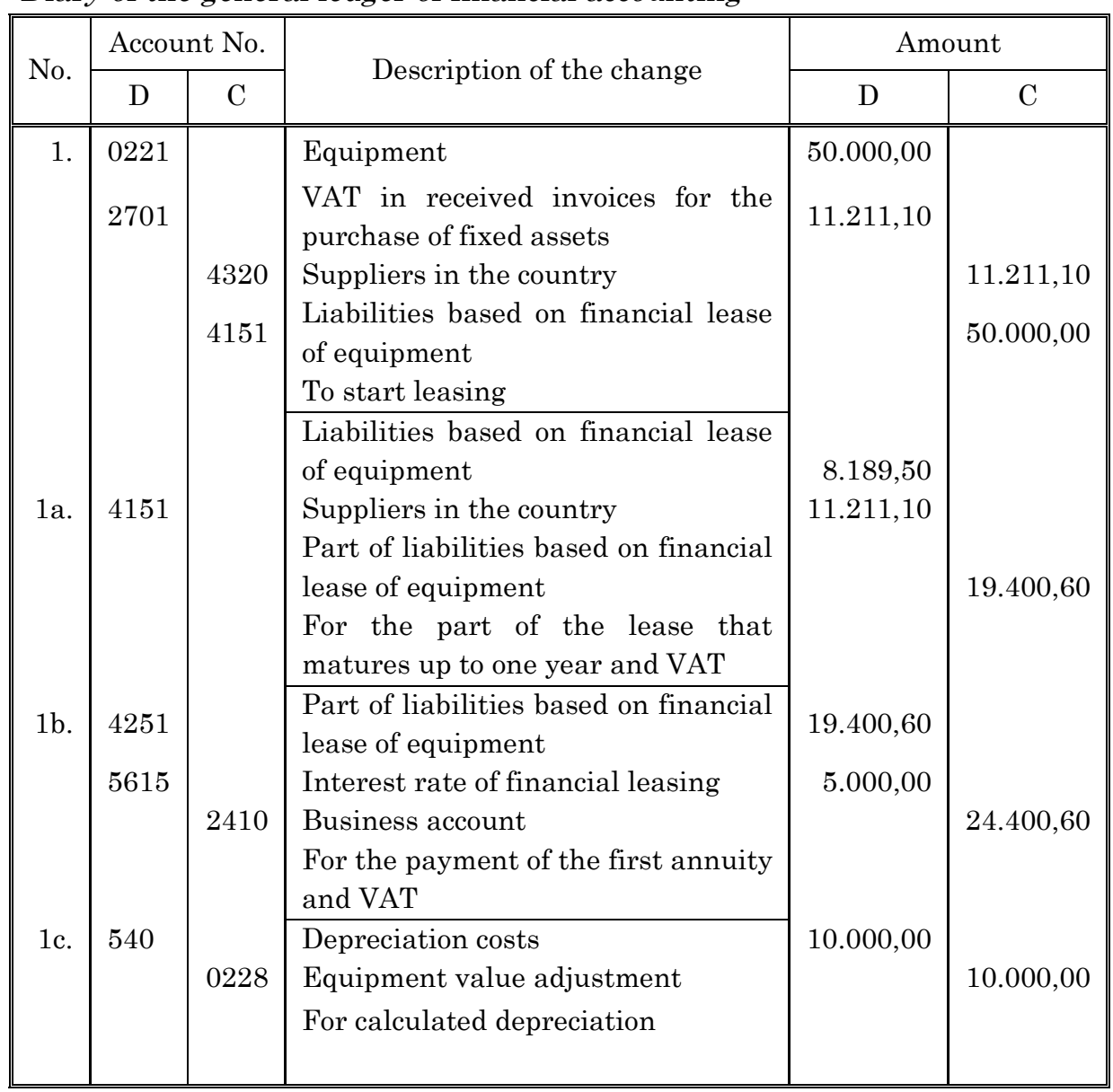


Lošić S. et al., Obtaining funds on the basis of leasing in the Republic of Srpska

Posting in the second year would be:

Diary of the general ledger of financial accounting

\begin{tabular}{|c|c|c|c|c|c|}
\hline \multirow{2}{*}{ No. } & \multicolumn{2}{|c|}{ Broj računa } & \multirow{2}{*}{ Description of the change } & \multicolumn{2}{|c|}{ Amount } \\
\hline & $\mathrm{D}$ & $\mathrm{C}$ & & $\mathrm{D}$ & $\mathrm{C}$ \\
\hline 1a. & 4151 & 4251 & $\begin{array}{l}\text { Liabilities based on financial lease of } \\
\text { equipment } \\
\text { Part of liabilities based on financial } \\
\text { lease of equipment } \\
\text { For the part of the lease that lasts up } \\
\text { to one year }\end{array}$ & $9.008,45$ & $9.008,45$ \\
\hline $1 b$. & 4251 & & $\begin{array}{l}\text { Part of liabilities based on financial } \\
\text { lease of equipment }\end{array}$ & $9.008,45$ & \\
\hline & 5615 & 2410 & $\begin{array}{l}\text { Interest expenses of financial leasing } \\
\text { Business account } \\
\text { To pay another annuity }\end{array}$ & $4.181,05$ & $13.189,50$ \\
\hline 1c. & 540 & 0228 & $\begin{array}{l}\text { Depreciation costs } \\
\text { Equipment value adjustment } \\
\text { For calculated depreciation }\end{array}$ & $10.000,00$ & $10.000,00$ \\
\hline
\end{tabular}

In the same way, the posting would continue in the third, fourth and fifth year according to the amounts determined in the annuity repayment plan.

\subsection{The impact of financial leasing on profit before taxation}

For the lessee, this effect is reflected in the reduction of profit before tax for the amount of interest expense incurred on the basis of financial leasing. In the above example, financial leasing lasts 5 years, and interest expenses on the basis of financial leasing expressed by years are: 1 year
5,000.00 KM, 2 years 4,181.05 KM, 3 years $3,280.20 \mathrm{KM}, 4$ years 2,289.25 KM and 5 year $1,197.00$ KM.

As can be seen, interest expenses are the highest in the first year of using the leasing arrangement. In the following years, the amount of interest expenses decreases. Accordingly, the profit before tax in these circumstances will decrease the most in the first year of using the leasing arrangement, while in the following years this reduction will be less and less. Assuming that instead of financial leasing, the legal entity purchased the equip- 
ment from its own sources, interest expenses on the basis of financial leasing would not even exist, so the profit before tax would be higher by the amount of expenses on the basis of interest on financial leasing.

In addition to interest expenses based on financial leasing, it would be interesting to consider the impact of the method of calculating VAT on the tax burden of the lessee. Namely, if the lessee, when concluding a financial leasing contract, agrees on the method of calculating VAT on the occurrence of financial leasing, in the above $\mathrm{ex}^{-}$ ample, VAT calculated on the basis of equipment purchase (input VAT) will be stated in the total amount. However, the output VAT that would result from the sale of effects produced by the given equipment will be equal to zero because the purchased equipment has not even started (or is just starting) with the sale of the effects produced with it. The advance (input) VAT will be higher than the calculated (output) VAT, and the lessee in this tax period (calendar month) would not have the obligation to pay VAT, but would be entitled to a refund of the difference in input tax or tax credit, which independently decides. Since the refund cannot be realized at the moment of determining the difference between input and output VAT, the lessee has "frozen cash" for the amount of the claim for the difference between input and output VAT.

If the lessee contracts the calculation of VAT in another way, ie. at the time of maturity of the annuity for collection, VAT (input) will be calculated on the amount of the due annuity. Compared to the first method of calculation, the calculated amount of VAT will be lower due to a smaller basis for calculation, and the output VAT that would arise from the sale of effects produced by the given equipment will be higher because the effects produced with the help of equipment acquired on financial leasing are already sold. The difference between input and output VAT will be smaller (or not at all), and the user of financial leasing will have less (or will not have) "frozen cash" based on claims for the difference between input and output VAT. It is noted that when analyzing the impact of the method of calculating VAT on the tax burden of the lessee, only the input and output VAT from the transaction of acquiring equipment on lease was analyzed, independently of other business transactions that occurred in that accounting period.

From the above, it can be concluded that the calculation of VAT at the time of leasing is less favorable for the lessee in terms of tax burden, 
and that it is more acceptable way to calculate VAT at the time of maturity of the annuity for payment. Therefore, when concluding a financial leasing contract, in addition to the price of equipment, interest rate and lease term, the lessee should pay attention and define in the contract the manner in which VAT will be calculated if the Law on Value Added Tax does not explicitly prescribe method of calculation.

\section{Conclusion}

The starting point for the choice of this topic was its importance and wider interest that primarily newly established, small and mediumsized legal entities have when making a decision on obtaining specific investment funds (real estate, equipment or consumer goods). It is an indisputable fact that in the conditions of economic and financial globalization of the world, newly established legal entities as well as medium and small legal entities, generally do not have enough own sources of financing to obtain expensive investment funds, which led to new methods of financing investment goods. In international business practice, the Leasing Agreement is one of those wellrepresented methods of financing. The advantage of this way of financing investment funds in relation to other forms of financing is reflected in the simplicity of procedures that do not require additional collateral, e.g. bills of exchange, mortgages, etc., specialization and experience of the lessor in terms of maintenance and servicing of leasing items, staff training, etc., which certainly benefits newly established, small and medium-sized legal entities. This way of financing allows the lessee greater accumulation and greater liquidity in further business. The lessee does not have to borrow on credit to place these funds for the purchase of investment goods, nor does the lease reduce its future creditworthiness through procurement. In that way, the lessee can borrow on credit for some other investment venture, if it is deemed necessary and justified.

But, regardless of the stated and other advantages, there are also certain disadvantages and risks that leasing operations bring with them, e.g. higher interest rates contained in the lease than nominal interest rates. Namely, for 2019. the interest rate contained in the lease - the weighted average effective leasing rate (ELIN) was 8.73, and the weighted average nominal interest rate (NIR) was $4.01^{8}$. Also, the non-existence of ownership over the acquired expensive investment goods during the term of the leasing contract, represents a serious risk for the lessee, especially if it is 
equipment that is technologically obsolete faster. In these cases, the possibility of complete depreciation of that equipment may be called into question.

The performance of financial leasing operations in the Republic of Srpska is regulated by the Law on Leasing, which was passed for the first time in 2007. All entities that

\section{References}

Brkić, A., (2014), Consumer protection in financial leasing contracts, Annals of the Faculty of Law in Zenica, 14: 275-326.

Dobrić, V., Jovićić, K., (2019), Legal (in) security of real estate leasing contracts in contemporary Serbian law, Annals of the Faculty of Law in Belgrade no. 2: 133-149.

Kronke, H., (2011), Financial leasing and its unification by UNIDROIT - General report. Uniform Law Review, Revue de Droit Uniforme 16: 24-45.

Laušević, L., (2014), Return leasing - an alternative source of increasing the working capital of the company, Bankarstvo no. 1: 30-63.

Petrović Z., Lošić, S., (2015), Accounting, University of Synergy, Bijeljina, p. 78. perform leasing operations in the Republic of Srpska have the obligation to comply with the prescribed legal provisions. Also, in accounting for transactions, leasing entities have an obligation to apply the requirements and rules contained in international standards applicable in the Republic of Srpska.

Petrović, Z., (2014), Financial Reporting, Singidunum University, Belgrade, p. 260.

International Financial Reporting Standards, (2010), SRR RS, SRR Srb., Banja Luka.

Law on Leasing ("Official Gazette of the Republic of Srpska" No. 70/07 and 116/11)

Rulebook on the chart of accounts and the content of accounts in the chart of accounts for companies, cooperatives, other legal entities and entrepreneurs who keep double-entry bookkeeping ("Official Gazette of RS" No. 79/09 and 99/14)

Banking Agency of Republika Srpska - BA RS (2020), Report on the situation in the banking system of Repu-blika Srpska for the period 01.01.-31.12.2019, www.abrs.ba,Visited: 10.05.2020 
Lošić S. et al., Obtaining funds on the basis of leasing in the Republic of Srpska

\footnotetext{
${ }^{1}$ Leasing Law ("Official Gazette of Republika Srpska" No. 70/07 and 116/11), Art. 4.

${ }^{2}$ Articles 4 and 6 of the Leasing Law

${ }^{3}$ International Financial Reporting Standards, (2010), SRR RS, SRR Srb., Banja Luka

${ }^{4}$ Article 2 of the Leasing Law

${ }^{5}$ Petrović Z., Financial Reporting, (2014), Singidunum University, Belgrade, p. 260.

${ }^{6}$ Petrović Z., Lošić S., Accounting, (2015), University of Synergy, Bijeljina, p. 78.

${ }^{7}$ The Rulebook on the chart of accounts and the content of accounts in the chart of accounts for companies, cooperatives, other legal entities and entrepreneurs who keep double-entry bookkeeping has been applied ("Official Gazette of RS" No. 79/09 and 99/14)

${ }^{8}$ www.abrs.ba RS Banking Agency, Report on the situation in the RS banking system 01.01. 31.12.2019. (accessed 10.05.2020.)
} 


\title{
PRIBAVLJANJE SREDSTAVA NA OSNOVU LIZINGA U REPUBLICI SRPSKOJ
}

\author{
Slavko Lošići ${ }^{1}$, Mirko Malinoviće ${ }^{2}$, Milica Jovanović ${ }^{3}$ \\ 12 Poslovna Akademija, Čačak \\ ${ }^{3}$ NovateQ Global
}

Korespondencija: slavko.losic@gmail.com

Rezime: Ovaj rad posvećen je lizing poslovima u Republici Srpskoj koji su uređeni Zakonom. Lizing je pravni posao gde davalac lizinga prenosi pravo držanja i korišćenja predmeta lizinga na primaoca lizinga na određeni rok, uz njegovu obavezu plaćanja ugovorene lizing naknade i sa pravom da predmet lizinga vrati davaocu lizinga, da ga otkupi ili da produži ugovor o lizingu.

Ovakav način finansiranja najviše koriste novoosnovana, mala i srednja preduzeća koja ne raspolažu sa većom sumom novčanih sredstava potrebnih za pribavljanje investicionih dobara. Sklapanjem ugovora o lizingu, primalac lizinga ne stiče pravo vlasništva nad predmetom lizinga, ali stiče ekonomske koristi od korišćenja predmeta lizinga. Ugovor o lizingu, obično se vremenski podudara sa korisnim vekom upotrebe sredstva, odnosno periodom obračuna amortizacije. Praksa je da se istekom ugovora, primaocu lizinga omogućuje da otkupi predmet lizinga i to po simboličnoj ceni.

Ključne reči: lizing, finansijski lizing, ugovor o lizingu, davalac lizinga, primalac lizinga, predmet lizinga, ekonomske koristi od predmeta lizinga. 